\title{
THE EPIDEMIC OF WHEAT STEM RUST (PUCCINIA GRAMINIS TRITICI) ON SPRING WHEAT IN SOUTH-WEST FINLAND IN 1951, PRIMARILY FROM THE BREEDER'S POINT OF VIEW
}

\author{
ERKKI I. KIVI \\ Plant Breeding Station Tammisto of Hankkija, Helsinge
}

Received February 27, 1956

\section{Introduction}

Puccinia graminis used previously to be very widespread and often destructive in the southern parts of Scandinavia, especially in Denmark. But it is now considered a plant disease of no economic significance in Northern Europe, particularly since the intermediate host of this rust species, Berberis vulgaris L., was destroyed by law in the most important catastrophe areas (9). Black stem rust has reappeared, it is true, but has done little damage and its occurrences have not reached epidemic proportions. Mostly the local occurrences have been associated with the appearance of the Berberis species susceptible to black stem rust. Black stem rust has been found in the neighbourhood of barberry bushes in Finland also (35).

The black stem rust epidemic of the summer of 1951, considering the circumstances reported above, was highly surprising $(5,14,26,40)$. In addition, it was so severe that no comparable epidemic has been observed, not even in the history of the experimental fields of the Svalöf Plant Breeding Station, i.e. not since 1886 (40). In Denmark, equally severe epidemics have been reported from before 1903 when the law ordering the destruction of the barberry bush was passed. The last catastrophic epidemic year prior to 1951 was 1901 (10). In the summers of 1936 and 1937, however, so much black stem rust was observed in different parts of Denmark that those years are considered there as epidemic years (5).

The occurrence of black stem rust in the summer of 1951 was more unexpected still in Finland than in Denmark and Sweden. In addition to the severity of the disease, a special characteristic of this outbreak was that the epidemic attacked wheat, in the southern parts of the epidemic area both autumn and spring wheat, 
and in Finland mainly the latter. When black stem rust occurred previously in this country it was oats that was infected most $(19,27)$. The wheat stem rust (Puccinia graminis tritici Erikss. \& Henn.) has not been nearly as widespread in this country as the ssp. avenae present in oats; it was reported by LIRO (18), as early as 1908, as a relatively general plant disease in South Finland.

In 1951, black stem rust began to occur in Finland on an alarming scale, after mid-August largely simultaneously in South-West Finland, South Ostrobothnia and South-East Finland (16). At Jokioinen, the observation post of the present author, the first occurrences were observed August 20, and a week later the epidemic reached its peak. The first observations in South Scandinavia had been made approximately a month previously $(31,40)$.

Research work dealing with the epidemic was carried out by the Agricultural Research Centre, Department of Plant Diseases, at Tikkurila (13), by the Department of Plant Breeding of the same Centre at Jokioinen (see further below), and special investigations e.g. by the State Institute for Seed Inspection (15) and State Institute for Technical Research, Foodstuffs Laboratory (33). The attention devoted to the epidemic is also reflected by the fact that the NJF Congress in Copenhagen in the summer of 1953 had chosen the black stem rust epidemic as the second topic for the section of plant diseases and plant pests $(14,17,20,32)$.

The purpose of the present study is to report, primarily from the plant breeder's point of view, on the investigations and observations made by the Agricultural Research Centre, Department of Plant Breeding, in connection with the occurrence of black stem rust on the different spring wheat varieties in South-West Finland and especially on the spring wheat material grown in the experimental fields of the Department of Plant Breeding at Jokioinen. Parts of the investigations have already been published in different contexts, primarily those related to practical farming $(16,25,26)$. Their results will be recapitulated in this paper as far as this is necessary for an overall picture.

\section{Material}

The experimental fields of the Agricultural Research Centre at Jokioinen came within the area of heavy attack of black stem rust (Fig. 1). This provided an excellent opportunity of observing the attack of black stem rust on the highly diversified selection of varieties and breeding material grown by the plant breeding station. Breeding for resistance to black stem rust is not especially included in the programme of Finnish plant breeders, just because of the insignificance of the disease; it followed, therefore, that black stem rust was quite abundant in the plant associations generally susceptible to the disease.

However, the use of the trial material of the plant breeding station for investigation purposes was greatly complicated by the fact that drought so hampered growth that e.g. comparative trial of spring wheat was not worth harvesting at all. Hence comparisons between the abundance of black stem rust and the grain yield by the method applied in Svalöf and its various branches the same summer 


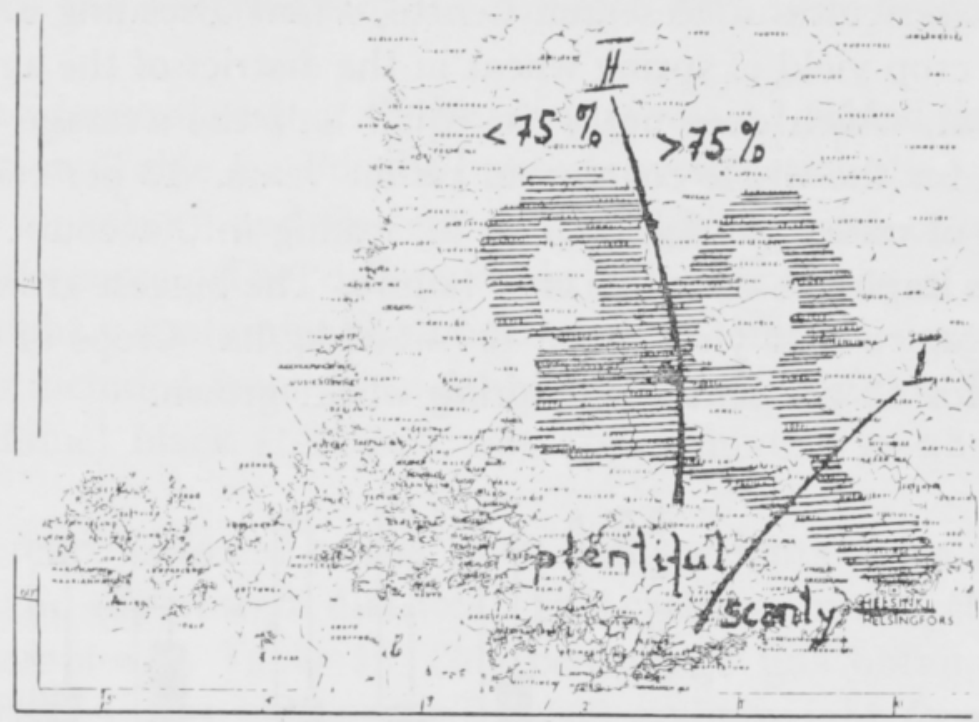

Fig. 1. The district investigated to throw light on the black stem rust epidemic in South-West Finland. Line I between the plentiful and scant occurrence of rust. Line II between the light and bad damage (1000 grain weight per cent of normal), at the same between western and eastern parts of district. (See p. 123.) The black triangle, Jokioinen.

(40) could not be carried out. In other respects the Swedish investigations under reference offer a good standard of comparison for several varieties were common to both selections of varieties.

In addition to the breeding station's own material, a material of 95 samples collected from different parts of South-West Finland (Fig. 1) was also treated. The abundance of black stem rust and the weight of 1000 grains was determined for all the samples. The samples were collected during four consecutive collection rounds $(26)$.

The amount of Puccinia glumarum was observed before the other rusts had occurred. The epidemic of black stem rust has started latest. The amount of black stem rust on leaves was therefore approximately small for at the time of start of epidemic the leaves of the most varieties were dried and in many cases full of other rusts. So, the mention "rust on leaves» means expressly the amount of Puccinia glumarum and P.triticina altogether, without separating them from each other.

All the laboratory determinations were carried out by the Agricultural Research Centre, Plant Breeding Department, in the course of winter 1951-52. Certain field trials were made in the summer of 1952 .

\section{Characteristics of the black stem rust epidemic of South-West Finland}

The economic losses from black stem rust were heaviest in the extreme southwestern part of the country. This is an important wheat growing district. The Agricultural Society of Varsinais-Suomi, operating in this district, made a statistical study of spring wheat crops to find out the extent to which the unfavourable conditions of summer 1951 had caused crop losses to the farmers. These statistics, made 
available to the Agricultural Research Centre, Plant Breeding Department, show that the average crop yield of spring wheat in the district of the agricultural society totalled $705 \mathrm{~kg} / \mathrm{ha}$, which does not even equal half the average crop per hectare usually obtained for the whole country in recent years. 13 per cent of the farmers had a crop yield of under $400 \mathrm{~kg} /$ ha (Fig. 2); taking into account the poor quality of the grains, this implied a complete crop failure. The biggest group of the samples, classified according to crop yield, gave $400-600 \mathrm{~kg} / \mathrm{ha}$. Crops of under $600 \mathrm{~kg}$ per hectare account for 43 per cent of all spring wheat grown.

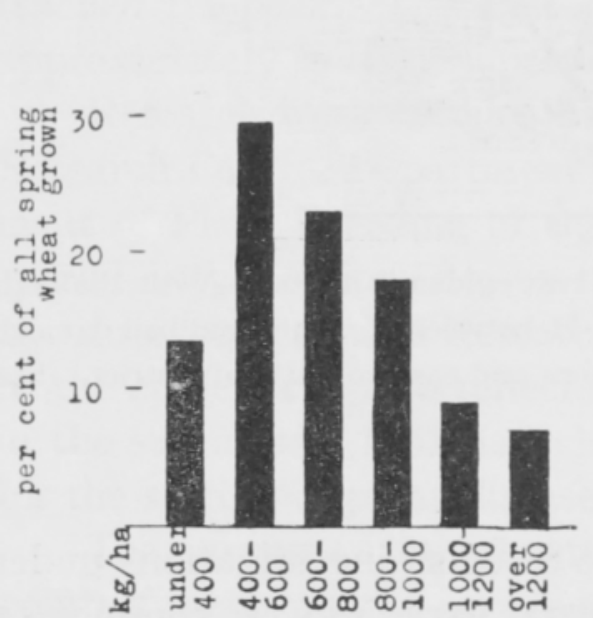

Fig. 2 .

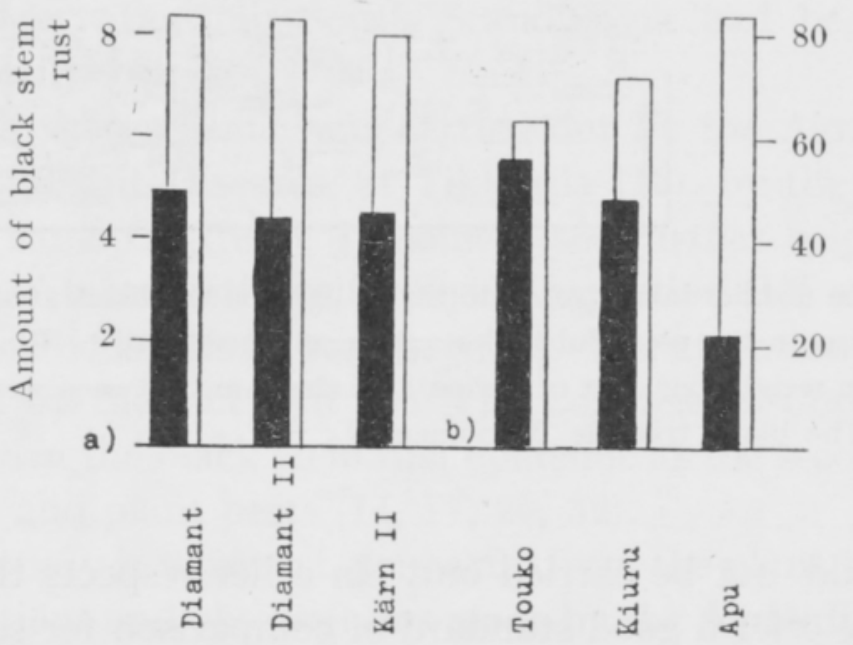

Fig. 3.

Fig. 2. Diagram showing the distribution of crops of different yields worked out on the basis of the spring wheat crop figures collected from the district of the Agricultural Society of Varsinais-Suomi. Mean crop $705 \mathrm{~kg} / \mathrm{ha}$. (Based on data supplied by the Agricultural Society of Varsinais-Suomi.)

Fig. 3. Degree of black stem rust infection (black column) and relative 1,000 grain weight (white column) of some varieties. (a) Diamant, Diamant II and Kärn II in the material collected from South-Finnish farms; (b) Touko, Kiuru and Apu according to samples collected from certain farms growing the relevant variety under contract.

In judging these figures, however, it should be borne in mind that the drought of summer 1951 was particularly catastrophic in South-West Finland. Hence the figures reflect the combined effect of black stem rust and drought, and in many cases drought may have been the greater evil-doer. According to official crop forecasts made before the onset of the black stem rust epidemic, the spring wheat crop should have been 80 per cent of normal. However, it is obvious that on habitats where growth was abnormally luxuriant black stem rust was more prominent than elsewhere and the crop yield remained negligibly low in any case (26).

All the samples collected from the farms showed black stem rust, and the average of amount of rust in samples throughout the area investigated was quite high (Fig. 1). An exception was a rather limited area in the neighbourhood of Helsinki where black stem rust was markedly less widespread than elsewhere. For instance, black stem rust was not nearly as abundant on the experimental fields of the Hankkija Plant Breeding Station near Helsinki as e.g. at Jokioinen, whereas Puccinia 
triticina, for which the conditions of the summer were very favourable, was widespread.

The mean incidence of rust on all the samples was 5.7, which shows the intensity of the contamination (Table 1). For the present investigation the whole area studied was divided into an eastern and western district (Fig. 1), each of which had certain characteristic differences. The difference in the abundance of rust is not very marked for the slighter contamination of the eastern samples is explicable primarily from the samples included from the neighbourhood of Helsinki. Elsewhere in this district (South Häme) black stem rust was approximately as abundant as in the western samples.

A clear difference is found in the 1,000 grain weights of the samples collected from the eastern and the western districts. This is shown in the relative 1,000 grain weights of the samples in Table 1 . This percentage was obtained by taking the weight of the 1950 crop as the "normal" 1,000 grain weight for each variety (as determined by the Agricultural Research Centre, Plant Breeding Department).

Table 1. Black stem rust in and 1000 grain weight of the spring wheat material collected from SouthWest Finland.

\begin{tabular}{|c|c|c|c|c|c|c|}
\hline District $^{1}$ ) & $\begin{array}{l}\text { No. of } \\
\text { samples }\end{array}$ & $\begin{array}{l}\text { Luxuriance } \\
\text { of growth }\end{array}$ & $\begin{array}{c}\text { Amount of } \\
0-10\end{array}$ & $\begin{array}{l}\text { ack stem rust } \\
\% \text { of samples } \\
\text { heavily } \\
\left.\text { infected }{ }^{2}\right)\end{array}$ & $\begin{array}{r}1000 \text { gra } \\
\% \text { of the } 1950 \\
1000 \text { grain } \\
\text { weight } \\
\text { ("normal") }\end{array}$ & $\begin{array}{l}\text { in weight } \\
\% \text { of samples } \\
\text { under } 75 \% \text { of } \\
\text { "normal" } 1000 \\
\text { grain weight }\end{array}$ \\
\hline Western $\quad \ldots \ldots \ldots$ & 53 & $7.1 \pm 0.41$ & $6.4 \pm 0.25$ & 95 & $66.5 \pm 3.41$ & 77 \\
\hline Eastern $\ldots \ldots \ldots$ & 42 & $8.3 \pm 0.09$ & $4.9 \pm 0.33$ & 75 & $91.6 \pm 4.20$ & 2 \\
\hline Total area $\ldots .$. & 95 & $7.7 \pm 0.02$ & $4.3 \pm 0.22$ & 86 & $77.9 \pm 2.84$ & 44 \\
\hline
\end{tabular}

1) Cf. Fig. 1

$\left.{ }^{2}\right)$ Samples with a rust index of 6.0 or more are classed as heavily infected.

A similar method was employed by the Swedish investigators (40). In the western district the 1,000 grain weights of the samples were only 66.5 per cent the corresponding value for the year before, in the eastern 91.6 per cent. The classification of the samples into badly damaged and slightly damaged was nearly the contrary in these areas. The 1,000 grain weight for the whole area was 77.9 per cent of the "normal».

A comparison of the luxuriance of growth reveals a slight difference in favour of the eastern district. Growth was clearly richer in South-Häme and Uusimaa than in the districts west of Jokioinen. However, a perceptible difference in growth was found also between the farming districts of Varsinais-Suomi and the Kokemäki River. The growth was poorest in the extreme south-western part of the area studied; these parishes belonged to the district of the Varsinais-Suomi Agricultural Society, in the north-eastern part of the worst drought area. A comparison of the samples collected from Varsinais-Suomi and the Kokemäki River district showed, however, that practically no difference obtained in the 1,000 grain weights; on the contrary, 
Table 2. Ratio of the amount of black stem rust to the relative 1,000 grain weight in the material specified in Table 1 .

\begin{tabular}{|c|c|c|c|c|}
\hline District & \multicolumn{3}{|c|}{$\begin{array}{c}\text { Amount of black stem rust } \\
\text { by classes }\end{array}$} & \\
\hline & $0-3$ & $4-6$ & $7-10$ & \multirow{5}{*}{ 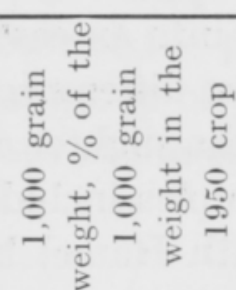 } \\
\hline Western $\ldots \ldots \ldots \ldots \ldots$. & 83.0 & 78.8 & 61.1 & \\
\hline Eastern $\ldots \ldots \ldots \ldots \ldots$. & 99.1 & 91.4 & 87.5 & \\
\hline Total area $\ldots \ldots \ldots \ldots$. & 97.8 & 81.2 & 69.4 & \\
\hline No. of samples ........ & 14 & 41 & 40 & \\
\hline
\end{tabular}

the lowest 1,000 grain weights' were recorded for some samples of fairly luxuriant growth from the latter district.

As samples from certain sloping lands could be taken from field under plough of highly varying luxuriance of growth, it was possible to show that black stem rust was most abundant at sites of the richest growth, and the 1,000 grain weight was lower than in places of poor growth (26). The effect of black stem rust on the grain was most marked just in those places where, due to luxuriant and at the same time late growth, the rust could survive better than in weak plant associations which, ripening rapidly, had partly matured too early.

However, a drop in the relative 1,000 grain weight with the amount of black stem rust increasing was clear throughout the area investigated and in its various parts (Table 2). The correlation coefficient between the amount of black stem rust and the 1,000 grain weight in the total material was $-0.77 \pm 0.04$; hence the correlation, considering the limited size of the material, was very strongly negative.

The fact that the drop in 1,000 grain weight due to black stem rust was perceptibly greater in the western than in the eastern district suggests that the epidemic definitely started earlier in the west than in Uusimaa and South Häme. The observations made in the early phases of the epidemic are on the same lines. As no great difference obtains between the western and eastern districts in the ripening time of crops (apart from fields that ripened too soon due to drought) an earlier onset of the epidemic at the same time meant that black stem rust in the western district could exercise its adverse effects at an earlier stage of development than where the epidemic started roughly at the time the crops were ripening.

\section{Notes on black stem rust in the spring wheat varieties grown in South-West Finland}

The spring wheat material collected from the farms contained three general varieties, Diamant, Diamant II and Kärn II, which together accounted for over three-quarters of the material. Nearly half of all the samples were Diamant wheat. As the remaining quarter is distributed between several varieties, only the three varieties listed can be studied in detail. In addition, material was collected from the new varieties of the Plant Breeding Department, called Touko, Kiuru and Apu, 
all of which were in propagation in the neighbourhood of Jokioinen in the summer under review.

The amount of black stem rust per variety was approximately the same (Fig. 3). In South Häme, Kärn II had been infected more than the other varieties, in Uusimaa Diamant II. Similarly the relative 1,000 grain weights of the different varieties were nearly equally much lower than the computed normal weight.

Of the new varieties of the Plant Breeding Department, Apu had best escaped infection by black stem rust (Fig. $3 \mathrm{~b}$ ). This was probably due to the early ripening of this variety, for Apu wheat is not known to possess any special resistance to black stem rust (24). This was also obvious from the observations of summer 1951 on certain farms sown a couple of weeks later than usual, due to delay in obtaining seed corn. By the time of ripening, Apu was a few days later than the fields sown at the normal time, and these late cultivations of Apu even showed plenty of black stem rust. Touko was the worst afflicted, and at the same time showed the lowest 1,000 grain weight. Kiuru also was badly contaminated by black stem rust.

\section{The incidence of wheat rusts in the breeding material at Jokioinen}

\section{Puccinia graminis, P.triticina and P. glumarum in the variety material}

During the growing season of 1951 observations were made of the occurrence of both black stem rust and the other wheat rusts in the trial field. The amount of P. triticina and P. glumarum present in the breeding material is always recorded as a matter of routine when it is great enough to permit the observation of differences between the varieties. A diagram of the results of observations of the different varieties included in the trials is given in Fig. 4; classification of varieties on the basis of these observations is shown in Table 3. The basis of classification was that applied by Ånerman \& Mac Key (40).

The observations revealed that the amount of black stem rust was considerably greater than that of other rusts. Yellow rust in particular was relatively scarce. The different black stem rust gradings given identical varieties in the different trials indicate that the amount of rust varied considerably by varieties even in such a limited area as the trial field of a single station.

Only certain American varieties, obtained as a result of deliberate breeding for resistance, were completely free from infection by black stem rust. The highly resistant varieties included only one non-American, Terä (= the line Ta 3455) bred by the Tammisto Plant Breeding Station. Its resistance emerged also on the Svalöf trial field in Sweden where it was awarded a grading of 7.8 for resistance to black stem rust (40). Among the known varieties, only the Swedish Pondus (7.9) proved equal to it at Svalöf; according to Swedish observations Pondus was the most resistant Swedish spring wheat variety (40).

Kärn II showed considerable resistance to black stem rust in Sweden, approximately the same as it did on the Jokioinen trial field (40). Diamant II, which at 


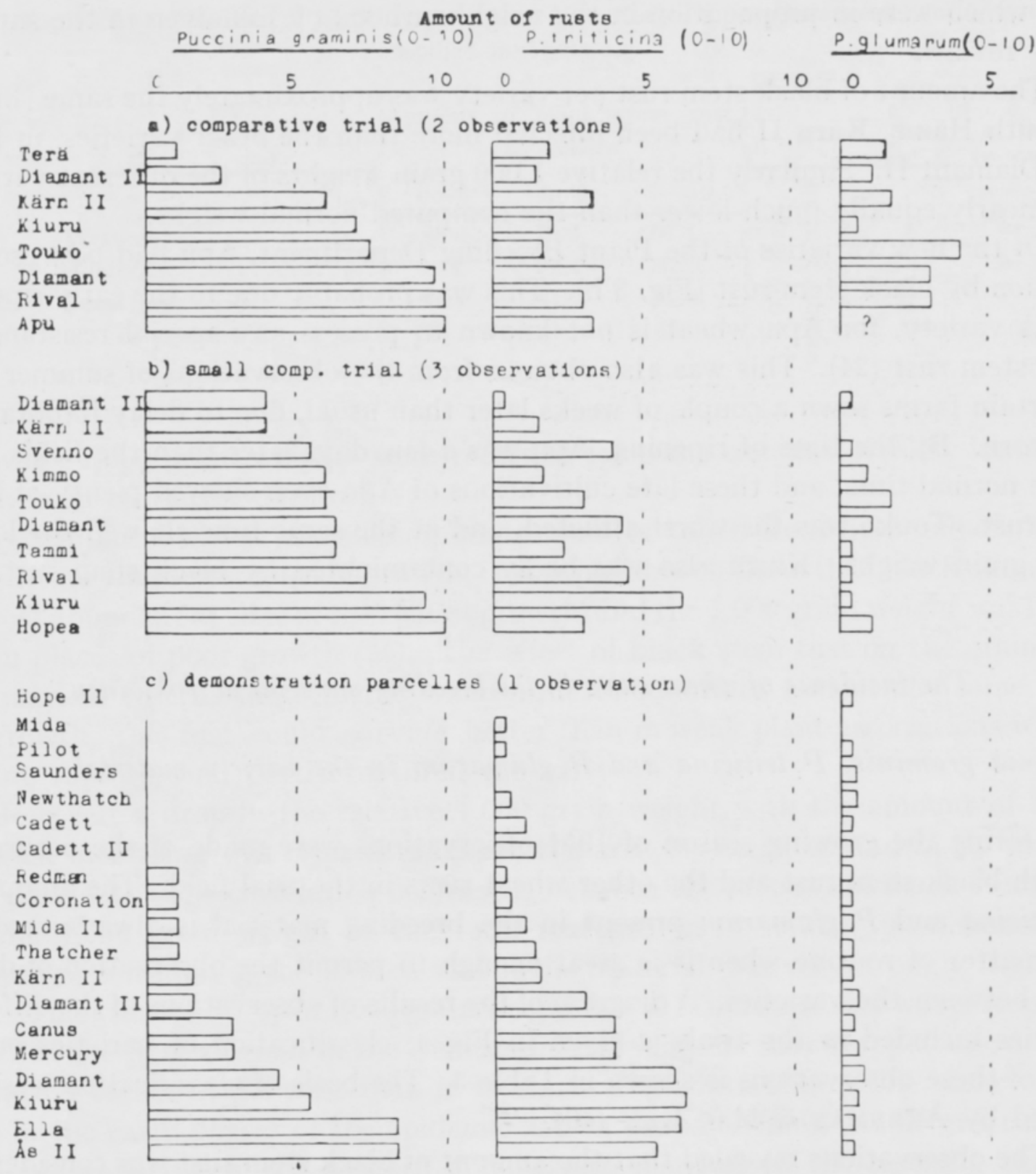

Fig. 4. The occurrence of wheat rusts (Puccinia graminis, P. triticina, and P.glumarum) in spring wheat varieties at Jokioinen, 1951. Observations made 8 th $(P$. glum. $)$ and 21st Aug. In the case several observations were made the amount of rusts here in the mean of all observations.

Jokioinen was roughly in the class of Kärn and less infected than the old Diamant, was quite susceptible to infection according to the Swedish observations. Diamant wheat was not included in the Swedish trials at all; hence a comparison between its susceptibility and that of the other varieties in different conditions is not possible.

Apart from Terä, all the Finnish varieties at Jokioinen were at least as badly infected as Diamant. Only Terä and Touko of the Finnish varieties were grown in the Svalöf trial fields; Touko was graded 4.5, i.e. similarly to Diamant II (40). 
Table 3. Resistance of spring wheat varieties to various rust species according to observations at Jokioinen in the summer of 1951. Classification according to Ånerman \& MAC KEY (40).

a) Puccinia graminis

Fully resistant: (Pilot) $\left.{ }^{1}\right),($ Hope II), (Mida), (Newthatch), (Cadet), (Cadet II), (Saunders)

Very resistant: Terä, (Thatcher), (Coronation), (Mida II), (Redman)

Fairly resistant: Diamant II, Kärn II, Pondus

Susceptible: Diamant, Touko, Tammi, Sopu, Kimmo, Hopea, Svenno, (Mercury), (Canus)

Highly susceptible: Apu, Kiuru, Hankkijan Ruskea, Rival, (Ella), (^̊s), (Ås II), (Fram II), (Snögg)

Fully resistant: (Hope II)

b) Puccinia triticina

Very resistant: Diamant II, (Pilot), (Mida), (Mida II), (Thatcher), (Newthatch), (Cadet), (Cadet II), (Redman)

Fairly resistant: Hopea, Kimmo, Tammi, Terä, Touko, Brons, Kärn II, Pondus, (Hankkijan Ruskea) Susceptible: $\quad$ Apu, Kiuru, Sopu, Rival, Diamant, (Ella), (Fram II), (Mercury), (Canus), (Rival)

Fully resistant: (Mida II)

c) Puccinia glumarum

Very resistant: All the remaining varieties

1) Varieties whose classification is based on a single observation are given in brackets.

If the material collected from the farms of South-West Finland is classified into "resistance groups» like the trial field material of Table 3 , the different varieties will be found to differ from the latter material to some extent:

\section{Susceptible: Diamant, Diamant II, Kärn II \\ Highly susceptible: Kiuru, Touko, Brons}

The observations were made about 10 days latter than they on the experimental fields at Jokioinen. The difference from the trial field observations is primarily that Diamant II and Kärn II were more heavily infected in the trial field, just as heavily as the Diamant; hence the difference between these varieties does not emerge in the farm material. Diamant and three highly susceptible varieties showed a relationship on the same lines as in the trial field where also the latter were more heavily infected than Diamant. The reason why Kärn II was much more heavily infected on the farms than in the trial fields may be that this variety, newly received and considered somewhat exacting, had been given the best habitats and maybe unusually good fertilization; the result was luxuriant growth and perhaps a consequent delay in ripening. Hence the variety was more susceptible to black stem rust than the other varieties of weaker growth, and hereditarily earlier even than Kärn II. The heavy infection of all the varieties on the farms may in fact be due to the epidemic being stronger in the western district than at Jokioinen. The growth on the trial field was of the weakest class but one seen in practical farming. 
The varieties that proved highly susceptible at Jokioinen, Ella and the Swedish Rival, were very heavily infected at Svalöf also (40). In addition, according to Swedish investigations, Ella showed a 1,000 grain weight more reduced relative to the amount of black stem rust than the others. Rival withstood black stem rust poorest of all at Svalöf. The Swedish Brons was relatively slightly infected at Svalöf, at Jokioinen heavily infected. The material collected from the farms included two samples of Brons, both very heavily infected.

Observations of the incidence of brown rust indicate that not all varieties resistant to black stem rust reacted similarly to brown rust although many had a similar resistance or susceptibility to all rust species. For instance, Kiuru showed a remarkable amount of brown rust, as did Diamant and Ella, all of which were relatively heavily infected by black stem rust also.

A general similarity in rust resistance, i.e. in resistance to the different rust species, is indicated in this material by the favourable reaction of the black stem rust-resistant American varieties in this part of the table also. Of the varieties that completely escaped black stem rust infection, Cadet II only showed clearly more brown rust than the others; but even then the amount was only as much as shown by Kärn II which was among the best non-American varieties. Canus and Mercury, which had plenty of brown rust, revealed no special resistance to black stem rust. Diamant II was the least infected of the non-American varieties. Most of the North European varieties, however, seemed fairly resistant to brown rust, definitely more so than to black stem rust.

The average occurrence of yellow rust was so slight compared with the other rusts that little deviation was noted between the varieties. As the classification in Table 3 is based on the mean values of observations at different trials the differences between observations are so levelled that this sort of classification by large intervals fails to reveal any differences at all. The American Mida II showed no yellow rust at all. The varieties susceptible to black stem rust, Touko, Diamant and Rival were in one trial (Fig. 4 a) more heavily infected than the others by yellow rust but in other trials $(4 \mathrm{~b}$ and $\mathrm{c}$ ) the difference was negligible.

\section{On the occurrence of rusts in populations and line material}

Rust observations were made with breeding material proper in the same way as with the varieties. The observations from some $\mathrm{F}_{2}$ populations are shown in Table 4. The amount of rust was estimated for each parcel in the same way as for the varieties; hence the figures provide a general picture of the average amount of rust in the population concerned. As with the varieties, yellow rust was relatively scarce. The only exception is the population (Sopu $\times$ Varma $) \times($ Sopu $\times$ Diamant $)$. The differences were greater in the occurrence of brown rust and black stem rust. The population (Sopu $\times$ Diamant $) \times$ Newthatch was most heavily infected by the former. It is remarkable that this population showed so much brown rust although Newthatch is one of the varieties with good resistance to rust (Fig. 4). On the other 
Table 4. Degree of rust infection in some $F_{2}$ populations at Jokioinen.

\begin{tabular}{|c|c|c|c|}
\hline Population & $\begin{array}{c}\text { P. gram. } \\
0-10 \\
\text { Aug. } 21\end{array}$ & $\begin{array}{l}\text { P. trit. } \\
0-10 \\
\text { Aug. } 21\end{array}$ & $\begin{array}{l}\text { P. glum. } \\
0-10 \\
\text { Aug. } 8\end{array}$ \\
\hline Diamant (standard) $\quad \ldots \ldots \ldots \ldots \ldots \ldots$ & 9.0 & 4.5 & 1.5 \\
\hline (Sopu $\mathrm{x}$ Diamant) $\mathrm{x}$ Newthatch $\ldots \ldots \ldots \ldots$ & 9.0 & 7.0 & 0.8 \\
\hline (Diam. $\mathrm{x}$ Sampo) $\mathrm{x}$ (Sopu $\mathrm{x}$ Diam.) $\ldots \ldots \ldots$ & 9.0 & 4.5 & 0.2 \\
\hline (Sopu $\mathrm{x}$ Varma) $\mathrm{x}$ (Sopu $\mathrm{x}$ Diam.) $\ldots \ldots \ldots$ & 10.0 & 4.2 & 5.8 \\
\hline$($ Sopu $\mathrm{x}$ Diam.) $\mathrm{x}$ (Review $\mathrm{x}$ Pissarev $\ldots \ldots$. & 9.0 & 2.5 & 0.5 \\
\hline (Janetzky x Diamant) $\mathrm{x}$ Kärn II $\ldots \ldots \ldots \ldots$ & 1.0 & 3.2 & 0.5 \\
\hline Kärn II x Apu $\ldots \ldots \ldots \ldots \ldots \ldots \ldots \ldots$ & 9.0 & 5.0 & 0.0 \\
\hline (Hopea $\mathrm{x}$ Diamant) $\mathrm{x}$ Rival $\ldots \ldots \ldots \ldots \ldots$ & 4.0 & 4.0 & 1.5 \\
\hline Kärn II $x$ (Kimmo $x$ Thatcber $\ldots \ldots \ldots \ldots$ & 5.0 & 4.0 & 0.0 \\
\hline
\end{tabular}

hand, Sopu and Diamant are fairly susceptible to rust. The most resistant population was $($ Sopu $\times$ Diamant $) \times($ Review $\times$ Pissarev $)$; its possible resistance can probably be traced back to the latter cross for the former pair was the same in the previous, most heavily infected population. The last-mentioned population was relatively light infected by black stem rust also. The population (Janetzky $\times$ Diamant $) \times$ Kärn II was even more resistant. Half the populations listed above were at least as badly infected by black stem rust as the standard used, Diamant. The population worst infected by black stem rust was $(\mathrm{Sopu} \times$ Varma $) \times($ Sopu $\times$ Diamant $)$, one which was very susceptible to yellow rust too. The effect of the American varieties Thatcher and Rival is probably reflected in the last two populations mentioned in the table which were less infected than the average.

By way of a summary of this youngest breeding material which was not selected in any way, it may be said that all the origins in general were badly infected by black stem rust; but other rusts, especially yellow rust, also occurred more often and in more variable degrees than on selected commercial varieties.

The line material in 1951 covered a total of 560 lines selected the year before from $32 \mathrm{~F}_{2}-\mathrm{F}_{8}$ populations. When individuals are selected from a population rust resistance is usually not taken into consideration as this is a factor easier to gauge later in the trial cultivation, primarily in pedigree sowings. Table 5 gives the average rust infection of lines of different origins; it provides an idea of the average rust susceptibility of each origin in the same way as for the $\mathrm{F}_{2}$ populations above. The observation method differs from the earlier in that the Puccinia triticina and P. glumarum present on the leaves were recorded together, without separate analysis, to accelerate the work. Diamant, used as the standard, was quite heavily infected by black stem rust. Arrangement of the origins according to the amount of black stem rust present showed the favourable effect of the American varieties, which had proved resistant to black stem rust on the same field, in the origins in which they had been employed as parents. All the origins at the top of the list included a resistant parent. A total of 10 of the origins had an American variety as a parent. The first nine origins of our 
Table 5. Average rust infection of the different origins in the pedigree material of spring wheat grown by the Plant Breeding Department, in summer 1951. Observations made Aug. 22.

\begin{tabular}{|c|c|c|}
\hline Origin & $\begin{array}{c}\text { P. gram. } \\
0-2\end{array}$ & $\begin{array}{l}\text { P. glum. + } \\
\text { P. trit. } \\
0-10\end{array}$ \\
\hline Mida II $x$ (Hopea $x$ Diamant) $\ldots \ldots \ldots \ldots$ & 0.2 & 2.6 \\
\hline Cadet II $\mathrm{x}$ (Hopea $\mathrm{x}$ Diamant) $\ldots \ldots \ldots \ldots$ & 0.2 & 2.0 \\
\hline Mida II $x$ Diamant $\ldots \ldots \ldots \ldots \ldots \ldots \ldots$ & 0.4 & 2.2 \\
\hline Mida II x (Aurore $\mathrm{x}$ Sopu) $\ldots \ldots \ldots \ldots \ldots$ & 0.5 & 1.6 \\
\hline Diamant $\mathrm{x}$ Mercury $\quad \ldots \ldots \ldots \ldots \ldots \ldots \ldots$ & 0.5 & 2.5 \\
\hline Renown $\mathrm{x}$ Sopu $\ldots \ldots \ldots \ldots \ldots \ldots \ldots \ldots \ldots$ & 0.6 & 2.3 \\
\hline Renown $\mathrm{x}$ Kimmo $\ldots \ldots \ldots \ldots \ldots \ldots \ldots \ldots$ & 0.8 & 4.3 \\
\hline Cadet II $x$ Diamant II $\ldots \ldots \ldots \ldots \ldots \ldots$ & 0.8 & 3.8 \\
\hline Sopu $\mathrm{x}$ Thatcher $\ldots \ldots \ldots \ldots \ldots \ldots \ldots \ldots \ldots \ldots$ & 0.9 & 4.6 \\
\hline R $055 \times$ Diamant $\ldots \ldots \ldots \ldots \ldots \ldots \ldots \ldots \ldots$ & 1.0 & 3.1 \\
\hline (Diamant $\mathrm{x}$ Hopea) $\mathrm{x}$ (Diam. $\mathrm{x}$ Tammi) $\ldots$. & 1.0 & 2.0 \\
\hline Sv. $1085 \times$ (Hopea $\times$ Diamant) $\ldots \ldots \ldots \ldots$ & 1.1 & 1.7 \\
\hline (Sopu $x$ Diamant) $x$ Diamant $\ldots \ldots \ldots \ldots$ & 1.1 & 1.9 \\
\hline Kärn II x (Aurore $\mathrm{x}$ Pika) $\ldots \ldots \ldots \ldots \ldots$ & 1.3 & 1.5 \\
\hline Kärn II $x$ Kimmo...$\ldots \ldots \ldots \ldots \ldots \ldots$ & 1.3 & 1.9 \\
\hline Diamant II x Diamant ................. & 1.3 & 3.7 \\
\hline Diamant II $x \AA$ As II $\ldots \ldots \ldots \ldots \ldots \ldots \ldots$ & 1.3 & 5.2 \\
\hline Diamant $\mathrm{x}$ (Tammi $\mathrm{x}$ Hopea) $\ldots \ldots \ldots \ldots . . .$. & 1.3 & 3.8 \\
\hline Diamant $x$ Renown $\ldots \ldots \ldots \ldots \ldots \ldots$ & 1.4 & 1.7 \\
\hline Diamant II $x$ Kimmo $\ldots \ldots \ldots \ldots \ldots \ldots$ & 1.4 & 3.5 \\
\hline Kärn II x (Aurore $x$ Pika) $\ldots \ldots \ldots \ldots \ldots$ & 1.4 & 1.9 \\
\hline Diamant II x Kärn II $\ldots \ldots \ldots \ldots \ldots \ldots$ & 1.4 & 2.3 \\
\hline Kärn II x Diamant $\ldots \ldots \ldots \ldots \ldots \ldots \ldots$ & 1.4 & 3.6 \\
\hline Tammi $x$ Diamant $\ldots \ldots \ldots \ldots \ldots \ldots \ldots$ & 1.4 & 2.1 \\
\hline (Diamant $\mathrm{x}$ Hopea) $\mathrm{x}$ (Sopu $\mathrm{x}$ Tammi) $\ldots$. & 1.4 & 4.9 \\
\hline 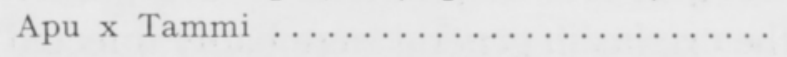 & 1.5 & 2.6 \\
\hline Diamant $\mathrm{x}$ (Aurore $\mathrm{x}$ Sopu) $\quad \ldots \ldots \ldots \ldots$ & 1.5 & 4.1 \\
\hline 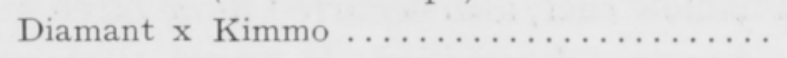 & 1.6 & 4.4 \\
\hline Diamant $\mathrm{x}$ (Aurore $\mathrm{x}$ Pika) $\ldots \ldots \ldots \ldots \ldots$ & 1.6 & 2.5 \\
\hline Sopu $\mathrm{x}$ (Diamant $\mathrm{x}$ Tammi) $\ldots \ldots \ldots \ldots$ & 1.6 & 3.9 \\
\hline Hopea $\mathrm{x}$ (Diamant $\mathrm{x}$ Tammi) $\ldots \ldots \ldots \ldots$ & 1.7 & 2.6 \\
\hline Hopea x Kärn II $\ldots \ldots \ldots \ldots \ldots \ldots \ldots \ldots \ldots$ & 1.8 & 5.9 \\
\hline
\end{tabular}

table come in this category, and only one, Diamant $\times$ Renown, was relatively heavily infected.

A study of the origins most susceptible to black stem rust draws the attention to the two most heavily infected; in both of these one of the parents was Hopea, very heavily infected in the trial field (Table 3 ). The parents of the heavily infected origins include such susceptible varieties as Tammi, Diamant, Kimmo, Apu and Pika (28). As a rule the parents of all the most heavily infected varieties consisted only of susceptible indigenous or Swedish varieties.

As regards the occurrence of the other rusts, the origins reacted to them similarly as the $\mathrm{F}_{2}$ populations; no distinct correlation existed between resistance to black 
stem rust and the other rusts. On the other hand, many origins that had resisted black stem rust well, e.g. Mida II $\times($ Aurore $\times \mathrm{Sopu}$ ), were resistant to the other rusts also. The origin most heavily infected by black stem rust, Hopea $\times$ Kärn II, showed very heavily infected by Puccinia glumarum and P. triticina too.

A study of the occurrence of the different rusts by lines revealed that a positive correlation seemed to obtain between the rust contamination of the leaves and the occurrence of black stem rust, which is visible from the following:

P. graminis on stalks (classes)

\begin{tabular}{|c|c|c|}
\hline \multirow{3}{*}{$\begin{array}{l}\text { rust- } \\
\text { free }\end{array}$} & \multicolumn{2}{|c|}{ infected } \\
\hline & & very \\
\hline & heavily & heavily \\
\hline 0 & 1 & 2 \\
\hline 1.9 & 2.8 & 3.2 \\
\hline 65 & 349 & 146 \\
\hline
\end{tabular}

The distribution of the lines by rust infection classes shows that the bulk of the material was heavily infected, and very heavily infected lines were considerably more numerous than the rust-free (which grade includes the lines very slightly infected, too). The proportion of the last-mentioned was a good one-sixth of all the lines. The amount is not surprisingly high as approx. one-third of all the origins included a parent variety that was resistant.

A small part of the line material was harvested in the autumn expressly for black stem rust studies. Forty-three unselected lines, marked by the breeder for one reason or another for discarding, from five origins were harvested. In the small material thus obtained, the abundance of black stem rust and the 1,000 grain weight were determined in detail in the laboratory. The results, by origins, are given in Table 6 . The 1,000 grain weight was lowest in origins whose lines showed the heaviest average black stem rust infection. Similarly, the leaves of the most heavily infected origins were heavily infected. The correlation between the amount of black stem rust and 1,000 grain weight (Fig. 5) was negative. The correlation coefficient was $-0.81 \pm 0.05$, which is very clear considering the limited size of the material.

Table 6. Rust infection and 1000 grain weight of the lines taken from certain origins, average figures, by origins.

\begin{tabular}{|c|c|c|c|c|}
\hline Origin & $\begin{array}{l}\text { No. of } \\
\text { lines }\end{array}$ & $\begin{array}{c}\text { P. gram. } \\
0-10 \\
\text { Aug. } 21\end{array}$ & $\begin{array}{l}\text { Rust on } \\
\text { leaves } \\
0-10 \\
\text { Aug. } 21\end{array}$ & $\begin{array}{c}\text { 1,000 grain } \\
\text { weight, } g\end{array}$ \\
\hline Rencwn $\mathrm{x}$ Sopu $\ldots \ldots \ldots$ & 12 & 4.2 & 2.6 & 35.1 \\
\hline Diamant $\mathrm{x}$ Kimmo ...... & 8 & 5.6 & 4.6 & 25.4 \\
\hline Mida II $x$ Diam......... & 10 & 2.4 & 2.5 & 37.0 \\
\hline Cadet II x Diamant II . & 6 & 4.2 & 4.2 & 31.4 \\
\hline Diam. II $x$ Ås II $\ldots .$. & 7 & 4.7 & 4.7 & 29.2 \\
\hline
\end{tabular}




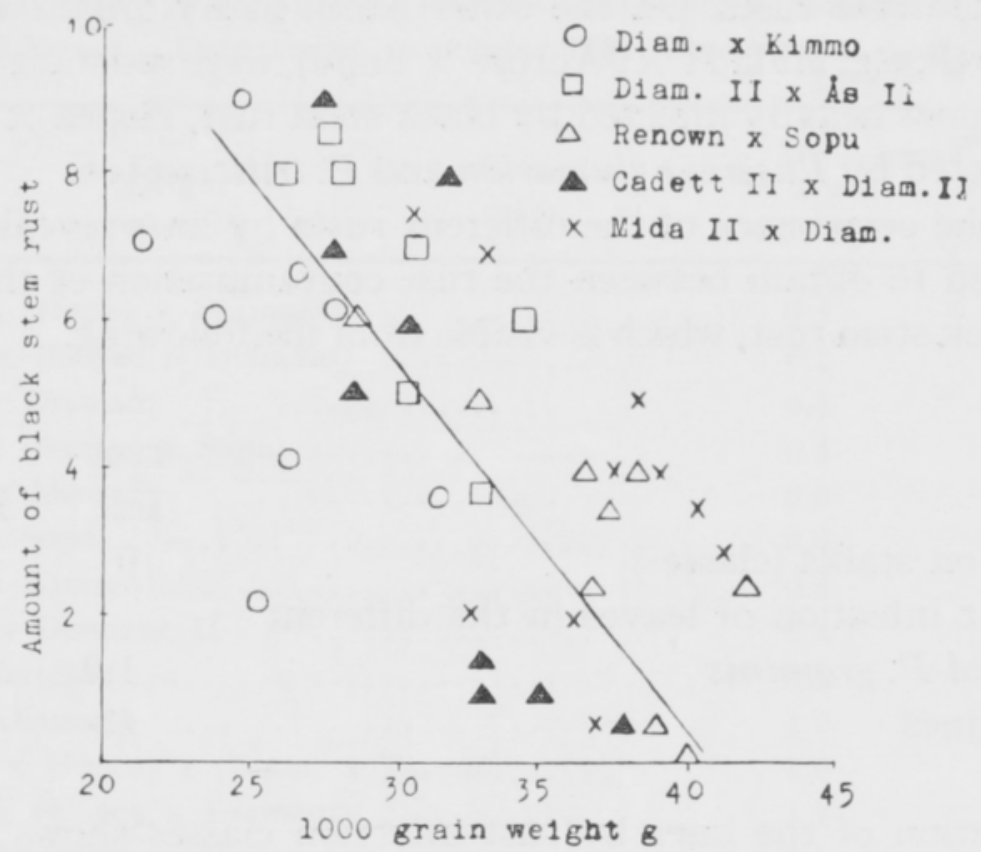

Fig. 5. Correlation between the 1,000 grain weight and degree of black stem rust infection in certain lines of five spring wheat populations.

However, it must be borne in mind that it was necessary to use the real 1,000 grain weights of the lines, with hereditary variation both within one and the same origin and especially between the origins. In most cases this variation is small compared with the variation due to black stem rust. As shown in Fig. 5, all the origins showed a negative correlation on similar lines to the correlation graph drawn for the total material.

The breeding material available shows clearly that resistance to black stem rust in our conditions has not been considered an important enough factor to warrant consideration in the indigenous material. The American varieties constitute a very special group as far as rust resistance is concerned; no Finnish variety reaches the same level, and this in spite of the variations present. It also seems that the incidence of other wheat rusts is higher in the Northern than in the American selection of varieties.

Significance of delay in growth for the occurrence of black stem rust

The growing season of 1951 was very late, one of the main factors responsible for the occurrence of the black stem rust epidemic (40). As pointed our before for $\mathrm{Apu}$ wheat, the late growth was found to be more heavily infected than the early (p. 125). A similar difference was observable in the trial field of the Plant Breeding Department between the sample squares of one and the same variety sown at different dates (Table 7). The growth sown at different dates were situated in adjacent squares, thus ensuring the greatest possible similarity of the other affecting factors. By ripening time the plants sown two weeks later were $5-7$ days behind 
Table 7. Effect of sowing date on the occurrence of rusts at Jokioinen in the summer of 1951.

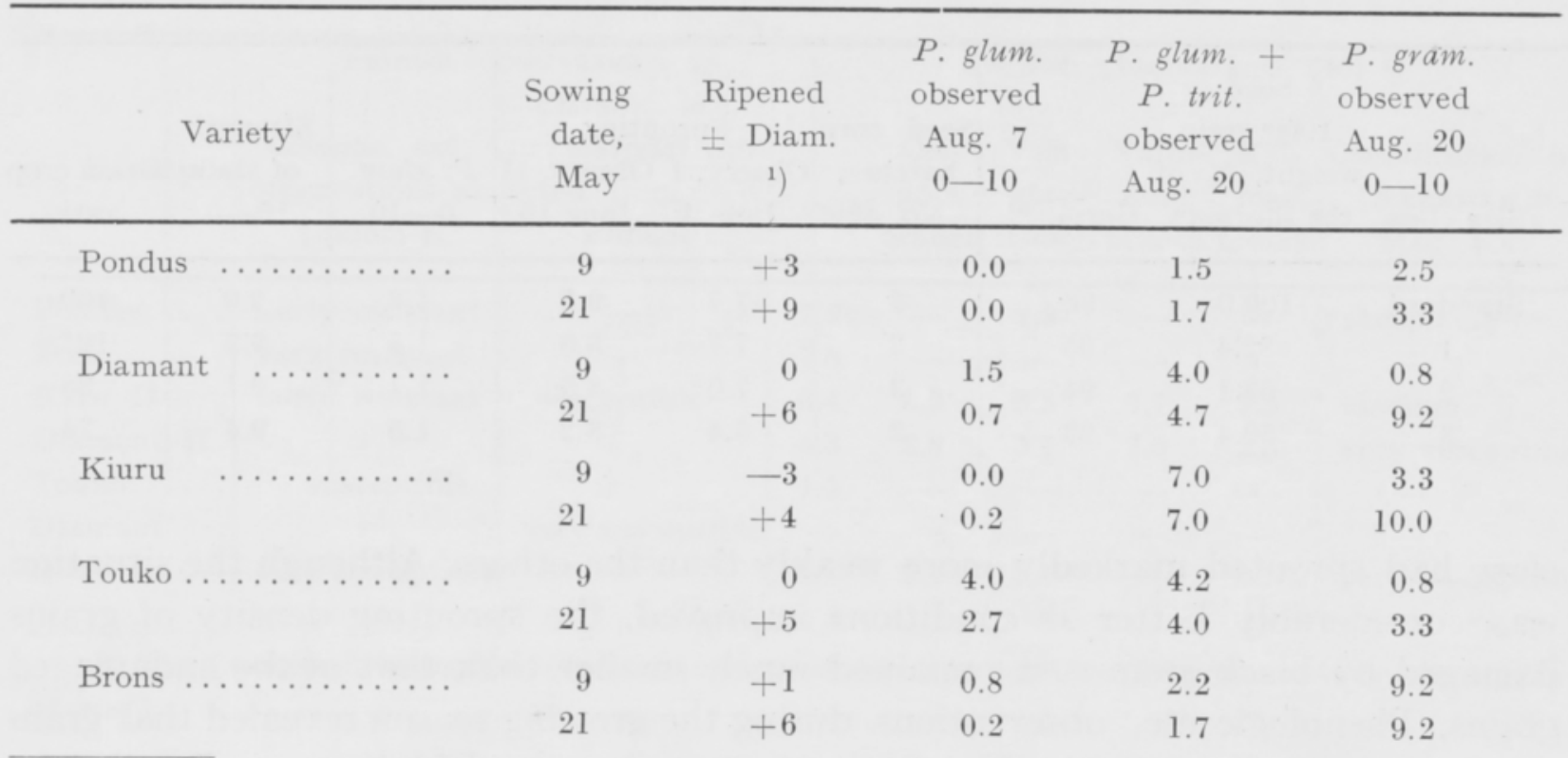

1) The early-sown Diamant is indicated by 0 ; the figure shows how many days earlier (-) or later $(+)$ than Diamant the variety concerned ripened.

the early sowing. Apart from Brons, the varieties showed a similarity in rust infection: the late growth was much more heavily infected. The late variety Brons was very badly infected in its early growth already. For Diamant and Kiuru the difference was considerable. Perhaps thanks to their early ripening, these varieties escaped heavy infection at a time when growth was sufficiently advanced to make them susceptible. The good resistance of Pondus, pointed out before (p. 125), emerged in this experiment also, for in spite of its late ripening it was infected least.

\section{On the properties of seed corn damaged by black stem rust and drought}

In spite of the outwardly heavy damage caused by the summer 1951 drought combined with the black stem rust epidemic, the germinability of the grains remained fairly good $(15,26)$. However, as there was reason to believe that in the conditions usually obtaining in a field under plough small grains would not sprout as well as those of normal size nor develop as well, an experiment was arranged in the summer of 1952 to examine the point. The trial comprised the three varieties Diamant, Touko and Kiuru, of which differently damaged grain batches and, for comparison, seed obtained from the 1950 crop were available. The seed corn batches in the trial were divided into three size classes (Table 8) according to the size of the grain. The varieties included gave highly similar results. The size of the grain had not affected the germinability of the seed appreciably, even though a slight decrease was observed with diminishing grain size. The conditions of summer 1952 were fairly unfavourable for sprouting and probably accentuated the weak sprouting of small-sized grains as compared with the standard and the normal-sized grains. Sprouting occurred in two phases. In particular the first showed that the smallest size 
Table 8. Use for seed of grains damaged by black stem rust and drought; results of one experiment series carried at Jokioinen in summer 1952, see p. 133 for details.

\begin{tabular}{|c|c|c|c|c|c|c|c|}
\hline Size class & $\begin{array}{l}\text { Seed } \\
1000 \text { grain } \\
\text { weight, } \% \text { of } \\
\text { the nnormal" }\end{array}$ & Germ. \% & $\begin{array}{l}\text { Seed corn } \\
\text { batches, } \\
\text { No. of }\end{array}$ & 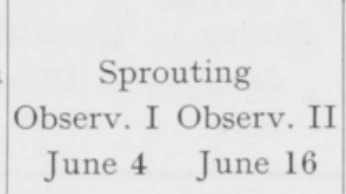 & $\begin{array}{c}\text { P. glum. } \\
0-10\end{array}$ & $\begin{array}{l}\text { Strength } \\
\text { of stalk } \\
10-0\end{array}$ & $\begin{array}{c}\text { Grain crop } \\
\text { ratio }\end{array}$ \\
\hline Standard & 100.0 & 96 & 3 & 9.3 & 1.2 & 9.0 & 100 \\
\hline 1 & 82.4 & 95 & 2 & 9.0 & 1.5 & 9.5 & 102 \\
\hline 2 & 63.1 & 94 & 3 & 8.5 & 1.1 & 9.1 & 88 \\
\hline 3 & 50.4 & 93 & 2 & 8.2 & 1.5 & 9.4 & 74 \\
\hline
\end{tabular}

class had sprouted markedly more weakly than the others. Although the situation was considerably better as conditions improved, the sprouting density of grains damaged by black stem rust remained much smaller than that of the undamaged grains. Phenologic etc. observations during the growing season revealed that grain size was of no importance in this phase. As regards crop yield, however, small-sized grains were very much below normal-sized grains. It is remarkable that the difference in crop yield between the two lowest grain size classes even was 14 per cent, although no great difference was observed in sprouting. It seems that the poorer crop yield from the damaged grains was not due exclusively to the smaller number of individuals per square unit but also to the smaller crop produced by the individuals that developed. As the individuals were not analysed separately this point remained unconfirmed.

\section{Discussion}

According to the observations reported above all the North European varieties were infected by black stem rust, and fairly heavily infected. Admittedly there were distinct differences between varieties. According to Finnish and Swedish experience from summer 1951, Terä and Pondus have the best resistance to black stem rust. Table 9 lists some of the most popular Finnish and Swedish commercial spring wheat varieties infected with black stem rust at various experimental stations both in Finland and Sweden. For Pondus and Terä the observations seem to be very much on the same lines; at Svalöf they were similar, and the difference reported from Jokioinen in favour of Terä is based on a small observation material. At the Västgöta branch, Sweden, Pondus was more resistant than the other varieties in the table. Swedish and Finnish observations differ slightly on the relationship Kärn II - Diamant II. In Finland the two varieties seemed roughly equally susceptible, in Sweden Diamant II seemed to have been more heavily infected than Kärn II at all the experimental stations. One of the factors responsible for this difference may be that the epidemic started so early in Sweden that the slightly earlier rifening date of Diamant lost its significance and the two varieties were infected in similar conditions; Kärn II was perhaps somewhat more resistant. In 
Table 9. Resistance tc black stem rust of some north European spring wheat varieties on the light of observations in Finland and Sweden.

\begin{tabular}{|c|c|c|c|c|c|c|c|c|}
\hline Variety & $\begin{array}{l}\text { Finnish ol } \\
\text { Classific. acc. } \\
\text { observations at } \\
\text { Jokioinen }\end{array}$ & $\begin{array}{l}\text { bservations } \\
\text { Classific. acc. } \\
\text { to material coll- } \\
\text { ected from S-W } \\
\text { Finland }\end{array}$ & Svalöf & $\begin{array}{l}\text { Öst- } \\
\text { göta } \\
\text { branch }\end{array}$ & $\begin{array}{l}\text { Väst- } \\
\text { göta }\end{array}$ & observa & $\begin{array}{l}\text { Kal- } \\
\text { mar } \\
\text { ranch }\end{array}$ & $\begin{array}{c}\text { Classification by } \\
\text { ÅKERMAN \& } \\
\text { MAC KEY }\end{array}$ \\
\hline 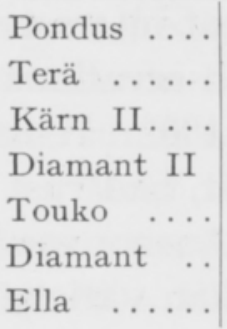 & $\begin{array}{c}\text { fairly resistant } \\
\text { very resistant } \\
\text { fairly resistant } \\
\text { susceptible } \\
\text { very susceptible }\end{array}$ & $\begin{array}{c}- \\
\text { - } \\
\text { susceptible } \\
\text { very susceptible } \\
\text { _ }\end{array}$ & $\begin{array}{l}7.9 \\
7.8 \\
5.4 \\
4.3 \\
4.5 \\
- \\
4.1\end{array}$ & $\begin{array}{l}- \\
- \\
5.3 \\
2.8 \\
- \\
- \\
5.1\end{array}$ & $\begin{array}{l}7.3 \\
- \\
6.3 \\
3.7 \\
- \\
-\end{array}$ & $\begin{array}{l}- \\
- \\
7.7 \\
7.0 \\
- \\
-\end{array}$ & $\begin{array}{l}- \\
- \\
7.5 \\
3.5 \\
- \\
-\end{array}$ & $\begin{array}{l}\text { acceptable } \\
\text { medium } \\
\text { very susceptibl } \\
\quad- \\
\text { - } \\
\text { very susceptibl }\end{array}$ \\
\hline
\end{tabular}

$\left.{ }^{1}\right)$ The Swedish investigations indicate rust resistance and not, like the present study, the amount of rust!

Finland, again, the late ripening of Kärn II made it slightly more susceptible at the outset of the epidemic than Diamant and favoured black stem rust (cf.p. 127). Diamant II and Touko, again, were largely similar in Finland and in Sweden. Similarly, Ella was one of the most susceptible varieties in both epidemic areas.

Although individual differences of this type were noted it seems that all the North European varieties, from the practical point of view, were too susceptible to black stem rust. The material collected from the farms of South-West Finland showed that Diamant II and Kärn II were very heavily infected (p. 127). Unfortunately no observations were available on Terä wheat which was at that time not an official commercial variety.

A study of the origin of the varieties shows the extent to which spring wheat material resistant to black stem rust was used in breeding work in Finland and Sweden. The bulk of the origins of our indigenous spring wheat varieties come from a fairly limited selection of varieties, among which Hankkija's Ruskea, Marquis and indigenous local strains can be considered basic (Fig. 6). According to American investigations (1) Marquis is a susceptible variety to many biological races of black

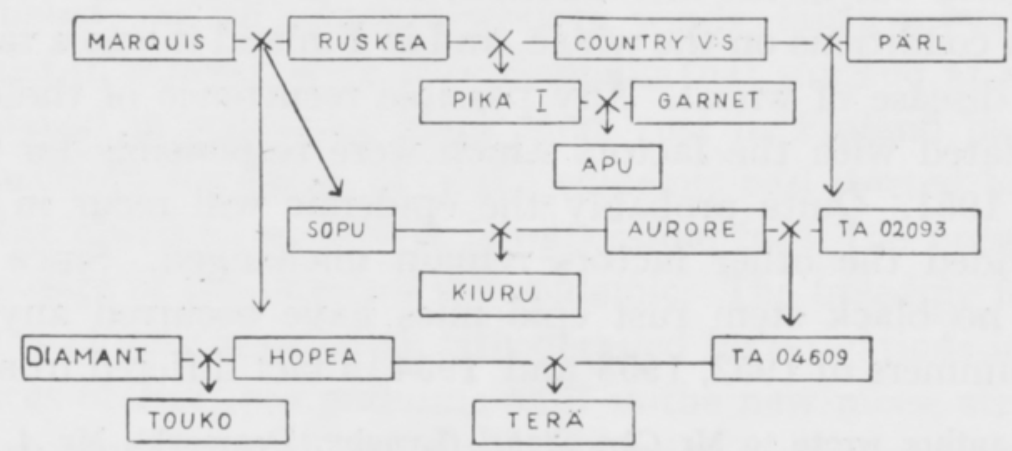

Fig. 6. The origins of finnish spring wheat varieties (after 11, 12, 21, 22 and 28). 
stem rust. Marquis is employed a great deal in America in crossings with varieties resistant to black stem rust because of its excellent practical properties. Ruskea was evidently rust-susceptible in general (28). As black stem rust has never been a factor of decisive importance in Finland there has been no selection for rust resistance in the local strains. In addition, natural selection would only occur in cases of very heavy infection as the rust, if present on a small scale, does not appreciably reduce the viability of the grains (cf. p. 134).

The good resistance to black stem rust shown by Terä is of very great interest. One of the parents, Hopea, was highly susceptible to the rust. No observations from the summer of 1951 are available on the other parent, line Ta 04609. It is possible that the other parent of this line, the Australian Aurore wheat, had rust resistance factors which were transferred to Terä. Admittedly, even Aurore was heavily infected in Sweden in some summers (40), but being an Australian variety it may be assumed to possess some rust resistance.

The varieties Kimmo and Tammi are of an origin completely different from the former (11). On the basis of the limited material available on both of them they seem susceptible to black stem rust.

Many of the spring wheat varieties generally grown in this country are of Swedish origin. The origins of the Swedish varieties are also confined to some few parents $(7,8,36,37,38,39,40)$. The oldest parents used by the Swedes are Kolben and Extra Kolben. Kolben, deriving from the German variety Heines Kolben (36), has previously proved fairly resistant to black stem rust in Sweden (40). Line Extra Kolben II, obtained from Extra Kolben, however, has proved to be of varying susceptibility in different years (40). Marquis and Aurore are the varieties from outside Europe most used in breeding work in Sweden also.

Thus the parents of the Finnish and Swedish varieties generally include no varieties resistant to black stem rust. Apart from the fact that black stem rust is considered of little importance, a natural reason for this is that the varieties obtained for the experiments from the black stem rust areas proper (U.S.A., Canada, Australia) are in some respects unsuitable for our conditions and hence have been little used in the crossings. These varieties have been introduced in the crossings recently, as will have been noted from the present investigation and the information published in Sweden (40).

As was pointed out in the introduction, the epidemic was relatively severe for North European conditions on the whole, and in Finland it was a rare phenomenon as an epidemic disease of wheat. Any possible recurrence of the epidemic will of course be associated with the factors which were responsible for the outbreak in the summer of 1951. Quite probably the epidemic will recur in similar weather conditions provided the other factors remain unchanged. Since the summer of 1951, however, no black stem rust epidemics have occurred anywhere in North Europe. ${ }^{1}$ The summers of 1952,1953 and 1954 in fact differed from the black stem

1 The present author wrote to Mr Chr. Stapel (Lyngby, Denmark), Mr A. Juel-Nielsen (Bornholm, Denmark), Mr J. MacKey (Svalöf, Sweden) and Mr I. Walstedt (Linköping, Sweden), all of whom reported that no black stem rust epidemic similar to that of summer 1951 occurred in $1952-55$. 
rust summer of 1951 on many points; hence the absence of rust in those summers might be attributed to weather conditions unfavourable for its development. But the summer of 1955 , at least in Finland, was in many respects similar to the black stem rust summer. The spring was cool, delaying growth considerably. July was warmer than the average, contrary to the case in summer 1951, but August was particularly warm and dry, as it was in 1951. Due to late sowing, cereals were broadly as delayed in developing as in 1951, although July did not retard growth as markedly as in that year. For black stem rust, then, weather conditions were similar in both these summers; in addition the growth of cereals was late in both the summers.

Most of the lectures on black stem rust delivered at the NJF Congress in Copenhagen dealt with the factors affecting the development of the epidemic (14, 17, $20,32)$. Black stem rust is not known to have occurred epidemically in Central Europe during the summer of 1951 (4), but epidemics in that year have been reported from Poland and Rumania (32, discussion). The present author inquired of Soviet researchers of the possible occurrence of black stem rust in Soviet territory in the summer concerned. The reply gave no direct indication of an epidemic in the northwestern parts of the country; however, rust had occurred on a scale permitting observations of differences in the resistance of some varieties. In addition, the present author had the opportunity of inquiring about the incidence of black stem rust in the North-Western Soviet Union when he met Russian plant pathologists in Leningrad in the autumn of 1953. According to them, no black stem rust epidemic occurred in the Baltic area of the Soviet in the summer of 1951, nor were they cognizant of any such epidemic elsewhere in the Soviet Union.

The present author has previously advanced the view that the Finnish black stem rust epidemic may have been secondary to the epidemics in South Scandinavia and Denmark, i.e. the rust responsible for the epidemic in Finland may have been carried here by air currents across the Baltic (16). In Finland the epidemic was severest in the south-western parts of the country, the areas most proximate to Scandinavia. As the epidemic in Finland started about a month later than in South Sweden the transport of sufficient spores by south-western and southern winds is quite feasible. The date of arrival (August 10-12) of the primary spores suggested in the present author's investigation quoted above, however, is too late for the arrival of the earliest infectors as the epidemic was distinctly observable just after mid-August. South to south-western winds, fairly prevalent in Finland during July-August in general, were very common that summer at other dates too. The part they played in spreading black stem rust in Finland has been pointed out in other connections too (34). Thus the epidemic had started before the above date, but as it was observed so late it is impossible from the present material to establish the true date of the onset of the epidemic. The breeding for resistance to black stem rust is closely associated with detailed investigations into the biology and biological races of Puccinia graminis as it is the new races, stronger than the former, that have caused the destructive epidemics recurring from time to time (e.g. 3). As far as is known, the physiological races have not been thoroughly studied 
anywhere in the Northern Countries, although some broad observations have been recorded $(2,6)$. Yet, according to investigations by American plant breeders (29), a thorough knowledge of these races is the basic condition for efficient breeding for resistance to black stem rust. Breeding for resistance to yellow and brown rust has been practised continuously in this country, and experience has shown that satisfactory practical results have been achieved. Resistance to yellow rust (Puccinia glumarum) has also been theoretically investigated in Finnish breeding material (21).

\section{Sum $m$ ary}

The paper reports on the black stem rust epidemic in South-West Finland in summer 1951, primarily from a plant breeder's point of view. The report is based on the material collected by the Agricultural Research Centre, Department of Plant Breeding, from the spring wheat cultivations of South-West Finland and the Department's trial field at Jokioinen.

1. Black stem rust was quite general in spring wheat throughout the southwest of Finland. In the extreme south-western part of the country the crop losses caused by drought and black stem rust were up to and over 50 per cent. In the eastern district of the area under review the damage by black stem rust was negligible in spite of heavy infection.

2. The coefficient of the correlation between the amount of black stem rust and 1,000 grain weight in the material collected from farms was $-0.77 \pm 0.04$, and in a material obtained from the trial field $-0.81 \pm 0.05$.

3. All the varieties grown in South-West Finland were susceptible to black stem rust. Kärn II, Diamant and Diamant II showed practically the same degree of infection. Thanks to its early ripening, the early Apu wheat in certain cases avoided heavy black stem rust infection.

4. On the trial field the north European varieties proved definitely more susceptible than many of the American varieties. Black stem rust was the most widespread of the wheat rusts in summer 1951 (cf. Table 3).

5. The younger breeding material revealed clearly the general susceptibility to black stem rust of the origins. It also showed the favourable effect on the descendants of the resistant parent strains employed in certain crosses.

6. A study of the origins of the Finnish varieties showed that hardly any varieties resistant to black stem rust have been employed as parents for our present commercial varieties.

Acknowledgements. The present work was carried out on the initiative and under the supervision of Prof. V. A. Pesola, Dr. of Agriculture and Forestry, Chief of the Agricultural Research Centre, Department for Plant Breeding. The author is indebted to him for the magnificent help given at all stages of the work. The author is also grateful to several of the staff of the Plant Breeding Department for help received at various stages; the contribution of Mr Orva InkiL $\ddot{A}$, Bach. of 
Agriculture and Forestry, deserves special mention. The Agricultural Research Centre, Department for Plant Breeding received a grant from the Ministry of Agriculture for the investigation of the black stem rust epidemic; the bulk of this grant was used in carrying out the present work.

\section{R E F E R E N C E S}

(1) Aamodt, O. S. 1927. A study of growth habit and rust reaction in crosses between Marquis, Kota and Kanred wheats. Phytopathology 17: 573-609.

(2) Anerud, K. 1951. Svartrosten och dess härjningar. Lantmannen 35: 659-660.

(3) Ausemus, E. R. 1950. Progress of breeding for stem rust, with particular reference to race $15 \mathrm{~B}$, at St. Paul, Minnesota. Rep. Wheat Stem Rust Conf. Univ. Farm Sta. St. Paul, Nov. 17._18. 1950: $10-12$.

(4) Black stem rust (Puccinia graminis) in Europe in 1951. Misc. Publ. Eur. Pl. Prot. Org. Paris 2 : $1-3$.

(5) Buchwald, N. F. \& Stapel, Chr. 1951. Sortrust og Berberis. Ugeskr. landm. 38.

(6) Ekstrand, H. 1955. Undersökningar över Berberis och svartrost I. Olika Berberis-arters mottaglighet för svartrost, Puccinia graminis PERs. Summary. Stat. växtskyddsanst. medd. 68: $1-74$.

(7) FAJERsSON, F. 1947. Weibulls original Kärnvårvete II. Weibulls illus. årsb. 42: 16 -17.

(8) —— 1950. Weibulls original Pondusvårvete. Ibid. 45: 3-7.

(9) Hamilton, L. M. 1936. Recent information regarding Barberry and Barberry laws outside North America. U. S. Dep. Agric. Bur. Ent. Plant Quar. 1936: 1-8. Mimeo.

(10) Hansen, R. 1923. Sortrustangrebenes Haefdighet i Danmark i Tiden 1884_1921. Nord. jordbr, forskn. 5 : $1-5$.

(11) Huttunen, E. 1946. Tammiston uusimmat kauppaan lasketut jalosteet. Hankkija, Siemenjulk. 1946: 128-29.

(12) - - 1950. Kevätvehnä. Summary. Ibid. 1950: 29-37.

(13) Jamalainen, E. A. 1953. Black stem rust and occurrence of Berberidaceae in Finland. Sci. Agric. Soc. Finl. 25: 47-53.

(14) Jörstad, I. 1954. Svartrustproblemet i Norge. Norf. jordbr. forskn. 36: 223-26.

(15) Kitunen, E. 1953. Valtion Siementarkastuslaitos. Toiminta 1. 9. 1951-30. 8. 1952. Summary. Maatal.hall. tied. 310: 1-49.

(16) Krvi, E. I. 1953. The causes of the black stem rust epidemic in Finland in summer 1951. J. Sci. Agric. Soc. Finl. 25: 147-52.

(17) Lindfors, TH. 1954. Förekomsten av berberis i Sverige. Nord. jordbr.forskn. 36: 241-44. (in discussion; P. Gröndtved, O. Pohjakallio).

(18) Liro, J. I. 1908. Uredinae Fennicae. Helsingfors.

(19) —- 1932. Viljan mustasta ruosteesta, joka tänä vuonna raivoo Etelä-Suomen kauramaissa. Pellervo 33: $610-12$.

(20) Mac Key, J. 1954. Svartrostbekämpning via växtförädlingen. Nord. jordbr.forskn. 36: $227-29$. (in discussion: D. Lihnell, H. Esbo).

(21) Pesola, V. A. 1927. Kevätvehnän keltaruosteenkestävyydestä. Summary. Valt. maatal.koet. julk. 8 : $1-76$.

(22) —- 1937. Jokioisten kevätvehnäjalosteet. Valt. maatal.koetoim. tied. 129: 1-20.

(23) —— 1953. Jokioisten uudet kevätvehnäjalosteet Apu, Touko ja Kiuru. Koetoim. ja käyt. 11, 2: 1, 4 .

(24) —- \& HonkavaAra, T. 1952. Apu-kevätvehnä, uusi aikainen kevätvehnäjaloste. Abstract: Apu wheat, a new Finnish early spring wheat variety. Valt. maatal.koetoim. tied. 228: $3-12$. 
(25) Pesola, V. A. \& Krvi, E. I. 1952. Svartrostens (Puccinia graminis) skadegörelse på vårvete senaste sommar. Tidskr. lantm. N:o 2.

(26) $\rightarrow-1952$. Tutkimus mustaruosteen tuhoista v. 1951 Lounais-Suomessa, erityisesti lajikkeita ja vahingon määrää silmällä pitäen. Reprint with Summary. Maatalous 45: 7-11.

(27) Pohjakallio, O. 1951. Om den ekonomiska betydelsen av vårsädens rostsjukdomar i Finland. Nord. jordbr.forskn. $33: \mathbf{4 8 0 - 4 8 5 .}$

(28) Sauli, J. O. 1935. Selostus Tammiston uusimmista kauppaan lasketuista jalosteista. Hankkija, Siemenjulk. 1935: 108-110.

(29) Stakman, E. C., Levine, M. N. \& Loegering, W. Q. 1944. Identifications of physiologic races of Puccinia graminis tritici. - U.S. Dep. Agric., Agric. Res. Adm., Bur. Ent. Pl. Quar. E-617.

(30) Stapel, Chr. 1951. Om sortrust og en bekaendgørelse om Berberis. Dansk landbr. Saertr., 4 p.

(31) —- 1951. Sortrustangrebenet på Bornholm i 1951. Planteavl på Bornholm, p. $30-32$.

(32) - - 1954. Sortrustangrebenet i Danmark i 1951. Nord. Jordbr. forsk. 36: 234-40. (In discussion: N. F. Buchwald, G. Weibull.)

(33) Veijola, T. 1951. Tämän vuoden mustaruostevehnä. Koetoim. ja käyt. 8, 12:3-4.

(34) Virri, T. J. 1953. Satakunnan kasvinviljelyskoeaseman koetuloksia v. 1945-52. Description: Result of experiments at the Satakunta experiment station (Period 1945-52). Valt. maatal.koet. tied. 231: $1-45$.

(35) Yцгмӓкі, A. 1947. Happomarjapensas mustaruosteen levittäjänä maassamme. Koetoim. ja käyt. 4, 12: $5-8$.

(36) Ånerman, Å. 1925. Vårvete. Svalöf, Allm. sv. utsädesakt. 1, $29-31$.

(37) —— 1928. Svalöfs Diamant vårvete. Ibid. 1, 17-19.

(38) - - 1934. Svalöfs Fylgiavårvete. Ibid., 8-13.

(39) —- 1940. Svalöfs Diamantvårvete II. Ibid. 1, 7-9.

(40) —— \& MAc KEY, J. et al. 1952. Vid Sveriges utsädesförening samlade erfarenheter från 1951 års svartrostangrepp. Summary. Sv. utsädesför. tidskr. 62, 75-151.

S E L OS T U S :

KESÄN 1951 MUSTARUOSTE-EPIDEMIA LOUNAIS-SUOMESSA ERITYISESTI KASVINJALOSTAJAN KANNALTA TARKASTELTUNA

ERKKI I. KIVI

\section{Hankkijan kasvinjalostuslaitos Tammisto, Helsingin pitäjä}

Kirjoituksessa käsitellään vuonna 1951 esiintynyttä vehnän mustaruoste-epidemiaa lähinnä Maatalouskoelaitoksen kasvinjalostusosaston toimesta kootun kevätvehnäaineiston ja sen koekentillä Jokioisissa tehtyjen havaintojen perusteella. Epidemian eri puolia on osittain saman aineiston perusteella käsitelty aikaisemmin eri yhteyksissä $(16,25,26)$. Tässä esityksessä tarkastellaan lähinnä mustaruosteen esiintymistä eri lajikkeissa ja kasvinjalostusosaston jalostusaineistossa. Mustaruosteen todetaan aiheuttaneen suurinta tuhoa tutkitun alueen (kuva 1) länsiosassa. Jokioisista itään mustaruostetta kylläkin esiintyi runsaasti, mutta sen vaikutukset jäivät verraten vähäisiksi. Heikko kevätvehnäsato maan lounaisimmassa osassa ei aiheutunut kuitenkaan yksin mustaruosteesta, vaan myös kuivuuden osuus oli huomattava.

Kasvinjalostusosaston runsaasta lajikevalikoimasta tehdyt havainnot osoittivat, että ainoastaan eräät amerikkalaiset jalosteet (Hope II, Mida, Pilot, Saunders, Newthatch, Cadet) olivat täysin välttäneet mustaruostesaastunnan. Kaikki pohjoiseurooppalaiset lajikkeet olivat yleensä pahoin mustaruosteen saastuttamia, mutta eri lajikkeiden välillä oli havaittavissa kestävyyseroja. Jokioisissa tehty- 
jen havaintojen mukaan vähimmin saastuneet pohjoiseurooppalaiset lajikkeet olivat ruotsalainen Pondus ja Tammiston Terä, jotka myös Ruotsissa osoittautuivat erittäin kestäviksi (40). Koekentällä Kärni oli vähemmän saastunut kuin Timantti. Kärni ja Timantti II olivat sekä koekentällä että käytännön viljelyksillä yhtä pahoin saastuneet. Ruotsalaisten havaintojen mukaan oli Kärni kestävämpi kuin Timantti II. Suomalaiset lajikkeet olivat Terää lukuunottamatta suunnilleen yhtä pahoin saastuneet kuin Timantti.

Kelta- ja ruskearuostetta lajikkeissa esiintyi vähemmän kuin mustaruostetta.

Pohjoismaissa suoritetussa kevätvehnän jalostustyössä ei yleensä ole käytetty mustaruosteenkestäviä lajikkeita risteytysvanhempina. Tämä johtuu lähinnä mustaruoste-epidemiain harvinaisuudesta meillä. Kasvinjalostusosaston aineistosta tehtyjen havaintojen mukaan mustaruosteenkestävien risteytysvanhempien käyttö on useimmassa tapauksessa selvästi lisännyt alkuperän keskimääräistä mustaruosteenkestävyyttä. 